\title{
Theory of the Subject as Pronoun
}

\author{
Rhoda Hanafi
}

\section{Théorie du sujet en tant que pronom}

La fonction principale des pronoms personnels est déictique. Remplaçant des noms propres, ils sont sans statut référentiel sauf dans une énonciation particulière. Cet aspect de la grammaire fournit un champ privilégié pour étudier la construction de la subjectivité, puisque les pronoms constituent un élément nécessaire de ce phénomène. La construction du sujet littéraire est encore plus problématique, puisquelesujetécrivant/écrit doitsesituerdoublement dans le temps et l'espace. Lorsque, dans l'écriture, un 'je' s'adresseà un 'tu/vous', lecteur, texte et écrivain participent dans un échange triangulaire des rôles représentés par les pronoms personnels. L'origo fixe du 'moi-ici-maintenant' déictique se transforme en un jeu kaléidoscopique, une scène changeante de la subjectivité. En écrivant des lettres à leurs enfants ou des journaux intimes, les femmes produisent des monologues déguisés en dialogue. Il s'agit d'un moyen de prolonger l'illusion qu'il soit possible d'écrire en dehors des idéologies patriarcales, en refusant d'accepter l'arbitraire du signe. 'Il/elle', la troisième personne, est une fiction exploitée par le mode de narration institutionnalisé dans le roman ou l'épopée. Par contre, quand le 'je' parleau 'tu', nous avons l'impression d'échapper à ce circuit, de communiquer directement, de façon transparente, avec l'autre, en contournant l'ordre symbolique.

\section{Spatially}

We cannot say anything about language or the functioning of language if we stay on the position of metalanguage. But language says something concerning itself in the permanent plays with its own categories, and that is what literary texts say. But it is not philosophical, it is not 
scientific. It is another practice of language, another status of the speaking subject. - Julia Kristeva, Semiotica, supp. (1981), p.217.

' $\mathrm{I}$ ' subject speak(s), tracing the imaginary conceptualized line between language and meta-language, infiltrating mySelf into the interstice that separates within and without. ${ }^{1}$ Not to talk about language but within language, narcotizing (blowing up, exaggerating) the permanent plays with its own categories. Speaking, saying: the very practice of the sujet en procès ${ }^{2}$ as it delineates its own within and without.

The boundary, then, of meta-/object, this oblique slash, shall provide the itinerary for this discourse - un parcours de discours - which, at once, fills up the interstice and traces out its boundary. Not a confine, no legal border, but a permanent play, a ceaseless diversion, on a detour from meta- ( $=$ 'beyond, transcending') to ... ?

But how do(es) ' $\mathrm{I}$ ' go beyond, transcending language? (And so she saw reflected in a double play of mirrors that old stand-by, mise en abyme, language reflected/ing in meta-language, an impoverished game of polished surfaces, false infinity trapped within the finite faces of narcissistic imaging.) There is no infinity here, no metasupposition, no transcendental language turning with-in in/to without. What contour do we (=you + me) grasp, which handholds do we grip, in order to turn 'language' inside out? Prestidigitation, then? A sort of intellectual mummery? Or another permanent play to show up other, unheard-of cracks between meta- and ...?

This interstice, then, is a hollow fiction: diction dictating discourse, and discourse dictating diction: a 'metaphyctional' fiction fissuring the solid wall of meta/language. It is in this crevice that ' $I$ ' insinuates itself, speaking, being spoken, taking on its own solidity as it fills up this heterogenous hollow.

\section{Temporally}

"' 1 " subject speak(s) ...' (t)here, presently, in full presence, tracing out its contour (do you see it?) by this writing. Locate it. Mark the spot.Signifying, signalling its presence in/by the signifier, it locates myself in the present-already-past. (A new tense: the tense of 'écriture': le présent-déjà-passé.)

Benveniste writes that 'ce "présent" ... n'a comme référence temporelle qu'une donnée linguistique: la coincidence de l'événementt 
décrit avecl'instance de discours quile décrit. ${ }^{3}$ Sheer coincidence, the present gives itself to conceptualization only in enunciation: a paltry sort of gift, this 'donnée linguistique' offers itself up only as a coinciding of event and description. So that in referring, in mentioning, the speaker utters a temporal reference, a sort of temporary refuge in an unco-ordinated space. Dismantled as it is erected, the present is reconstructed in/by the peripatetic peripheries of the signifier.

\section{Presently}

On arrive ainsi à cette constatation-surprenanteà première vue, mais profondément accordée à la nature réelle du langage - que le seul temps inhérent à la langue est le présent axial du discours, et que ce présentest implicite. Il détermine deux autres références temporelles; celles-cisont nécéssairement explicitées dans un signifiant et en retour font apparaître le présent comme un ligne de séparation entre ce qui n'est plus présent et ce qui va être. - Emile Benveniste, Problèmes du langage, Benveniste et al. (Paris: Gallimard, 1966), p.9.

The present is implicit in speech as it is inherent to language. By stating ' $I$, I locate(s) a 'generating axial centre,' a temporal/spatial axis. A line, then, of affirmation and separation: affirming 'now' and 'here,' yet separating present from past/future, ' $\mathrm{I}$ ' rends as it renders, parting, splitting what no longer is from what may be, yet simultaneously defining the very possibility for that split.

This line of separation is affirmed, however, only in discourse: ' $C$ ' est dans l' instance de discours où je désigne le locuteur que celui-ci s'énonce comme "sujet." S4 Speaker and subject synonymize in discourse; the ' $\mathrm{I}$ ' speaks itSelf in/onto a graphic location through pronominal appropriation. Subjectivity in these terms is nothing other than the locus of locution, a plotting of the person on a time/space continuum in the precise instance of speech.

Two intersecting perpendicular strokes on the page can serve as a coordinate system for us with $\mathrm{O}$ as the origo, the point of origin for the coordinates:

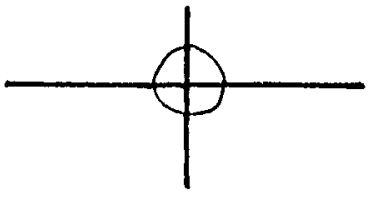


I maintain that three deictic words must be put at the place of $\mathrm{O}$, if this scheme is to represent the deictic field of human language, namely the deictic words here, now, and $I$. These lexical items, so simple in their sound structure, might induce the language theorist into esoteric philosophical abysses or to respectful silence, when challenged to determine their function. Rather, he should simply acknowledge that it is certainly very peculiar, but nevertheless precisely statable, how they function in a concrete utterance. $^{5}$

The $\mathrm{O}$, origo of indexical reference is a dangerous abyss which ' $\mathrm{I}$ ' skirts either by remaining respectfully silent or by concretizing itSelf in utterance. ' 1 ' does not symbolize or name, $\mathrm{L} / \mathrm{it}$ denote(s) nothing but its/my presence, pointing directly to an original point of reference: the origo of subjectivity. Deictic gestures that indicate nothing but the point of origin in speech, ' $\mathrm{I}$, 'here' and 'now' 'demand that they be characterized as signals' thus distinguishing themselves from the naming words, which 'function as symbols, and receive their specific complete and precise meaning within the synsemantic field. ${ }^{6}$ Excluded from meaning as a conventional (syntactic/semantic) field of sign-functions, deictic markers take up residence only on the outskirts of the symbolic fields, in a situational, contextual cross-current of temporary forces. ${ }^{7}$

As Benveniste writes: '[Les pronoms] se distinguent de toutes les designations que la langue articule, en ceci: ils ne renvoient $n i$ à un concept ni à un individu. '8 'Singulier,' 9 'peculiar,' ${ }^{10}$ 'staggering,' or 'scandalous, ${ }^{\prime 1}$ ' $I$ ' is the nomadic nomenclature for a nonproductive, nonexistent nomination.

\section{I and You}

(If they are to be human, they must be at least two in number.)

- Alexandre Kojève, Introduction to the Reading of Hegel, ed. Allan Bloom, trans. James Nichols, Jr. (Ithaca: Cornell U.P., 1980), p. 43.

Le langage n'est possible que parce que chaque locuteur se pose comme sujet, en renvoyant à lui-même comme je dans son discours. De cefait, je pose une autre personne, celle qui, tout extérieure qu' elle est à 'moi,' devient mon echo auquel je dis tu et qui me dit tu. [...] Cette polariténe 
signifie pas égalité ni symétrie: 'ego' a toujours une position de transcendance à l'egard de tu; néanmoins, aucun des deux termes ne se conçoit sans l'autre; ils sont complémentaires, mais selon une opposition 'intérieur/extérieur,' et en même temps ils sont réversibles.

- Emile Benveniste, Problèmes de linguistiques générales (Paris: Gallimard, 1966), p. 260.

As ' $\mathrm{I}$ ' explore(s) the confines of subjectivity, running back and forth along the border of meta/language, necessarily implicating my/itSelf in a non-symbolic, deictic field, and at once, circumscribing the origo of referential speech, 'I' also, by my/its very allocution, allocate(s) another in my/its subjective economy. Within and without, 'vers l'intérieur' and 'vers l'extérieur,' are the reversible sides of an isolating membrane which inwardly and outwardly designs the structures and regions of the communication act. This common border is a resonating surface, enclosing an echoing chamber of the person: ' $\mathrm{I}$ ' speak(s), say(s) my/itSelf and simultaneously hear(s) echoed back the voice of 'you,' a voice that paradoxically originates with, and within, the isolating confines of 'me.' The person, like the present, both affirms and separates: affirms itSelf in the appropriation of the personal pronoun, and separates itSelf from the exterior in the instant substantiation of the other, 'you.'

If neither equal nor symmetrical, however, how is this 'polarity of persons' to be characterized?

La subjectivité se laisse localiser un instant dans une stase pronominale qui, sans être isolée en soi, maintient des relations définies avec les autres. Du point de vue de cette instantanéïté de la subjectivité dans l'usage normatif du langage, l'ego toujours transcendental et surplombant l'allocution, ne s'isole qu'en $\mathrm{s}^{\prime}$ opposant à $t u .^{12}$

Subjectivity is not any thing: it is a motionlessness, an instantaneous stasis in a pronominal equilibrium brought on by a relational positing of ' $\mathrm{I}$ ' and others. 'Ego' remains 'transcendental and overhanging allocution,' silently poised on the outward rim of speech, over and above the localising effect of discursive orientation. But in utterance, division and complementarity: an instantaneous splitting of the 'forever transcendental' I which cleaves itself into the opposi- 
tional sides of the same, reversible (non-)duality: ' $I$ ' becomes 'you,' and 'you,' 'I,' so that 'you' is both other and the same; not a difference, but rather a question of positionality on the self-same axis.

La conscience de soi n'est possible que si elle s'éprouve par contraste. Je n'emploie je qu'en m'adressant à quelqu'un, qui sera dans mon allocution un $t u$. C'est cette condition de dialogue qui est constitutive de la personne, car elle implique en réciprocité que je deviens $t u$ dans l'allocution de celui qui à son tour se désigne par je. ${ }^{13}$

Ainsi ne s'étonnera-t-on pas de constater que 'tu' est une façon de nommer 'je,' que 'tu' cache 'je.' ${ }^{14}$

Allocution thus implies dialogue and reciprocity: a speech drama in which the personae exchange the masks of their person ${ }^{15}$ in a reciprocal play of pronominal cache-cache (hide-and-seek). A strange game, paradoxically contrived, in which the players reveal themselves through speech, call attention to their own presence, and affirm to themselves their Selves, while at the same time implicating the other through a reciprocal gift of persona, thus masking, covering up, and assuming the pretence of pronominal allocation in an endless series of moves, stases and hypostases.

Subjectivity is not any thing: it is the itinerant effect of an incessant positing and posing of the person, a double play that calls into action ' $\mathrm{I}$ ' and 'You' in a perpetual game of revealment and masking.

\section{S/he}

Dans les deux premières personnes, il y a à la fois une personne impliquée et un discours sur cette personne. 'Je' désigne celui qui parle et implique en même temps un énoncésurle compte de 'je': disant' $j e$, ' je ne puis pas parler de moi. A la $2 e$ personne, 'tu' est nécéssairement désigné par 'je'; et, en même temps, 'je' énonce quelque chose comme prédicat de 'tu.' Mais de la 3e personne, un prédicat est bien énoncé, seulement hors de 'je-tu'; cette forme est ainsi exceptée de la relation par laquelle ' $j e$ ' et 'tu' se spécifient. Dès lors la légitimité de cette forme comme 'personne' se trouve mise en question.

- Benveniste, PLG, 228. 
[I]l est méchant: $c^{\prime}$ est le mot le plus méchant de la langue: pronom de la non-personne, il annule et mortifie son référant; on ne peut l'appliquer sans malaise à qui l'on aime; disant de quelqu'un 'il,' $j$ 'ai toujours en vue une sorte de meutre par le langage....

- Roland Barthes, Roland Barthes (Paris:Seuil, 1975), p. 171.

' $\mathrm{I}$ ' and 'you' engaged in conversation; as we exchange the masks of person in a mutual reaffirmation of the status of subject, we implicate each other in our deictic fields, revealing the presence of our personhood through our enunciation. ' $I$ ' say(s) 's/he,' and this utterance immediately points to a reference outside our shared coordinate system, a point exterior to the echoing chamber constituted by our discourse. 'S/he' is an absent entity, designating no one in particularor an unspecified multiplicity of persons. ${ }^{16}$ The third person is a misnomer, since the person it calls up is not, is a non-person, forever excluded from the intimate reference of personal dialogue.

This murderous appellation distances the third other from any access to the origo of subjectivity, and as such only names the possibility of person. It is thus a hypothetical nomenclature, the fictional person par excellence. ${ }^{17}$

If 's / he' is annulled and mortified, hypothetisized and fictionalized, 's/he' also opens up for ' $\mathrm{I}$ ' a route to a meta-linguistic promontory:

Si l'énonciation se fixait en un 'il' ainsi isolé de l'allocution, elle pourrait $s^{\prime}$ articuler comme une métalangage ou comme une contemplation: tenu par un sujet forclos, soumis a la loi ou usurpant sa place. ${ }^{18}$

'S/he' is the mark of an utterance issued by a foreclosed subject, one who is debarred from the linguistic Eden of innocent speech. For ' $I$ ' to name an absent (non-)person or to refer to a point outside of the deictic field of the discursive instant, ' $I$ ' must first of all conceive of that exterior, that other place, in order to 'plan the murder' from a transcendental position of self-conscious linguistic knowledge.

The third person is indeed a meta-fictional construct since its use sets up a distancing effect, first by removing the subjective ' $\mathrm{I}$ ' from the third other while placing it in a field outside of the dialogical reference 
coordinates of 'we,' relegating 's/he' to the status of non-person and thus setting up an unbroachable dichotomy between 'us' inside, located, allocated in the discursive instant, and 'them,' outside, unlocatable, multiple, hypothetical creations of language. Secondly, 's/he' distances the speaking ' $\mathrm{I}$ ' from speech itself, by calling attention to the unnatural artifice of pronominal naming: where denotation is called into question, where 'only one' and 'many' are designated by the same term, the implicit transparency of the here-and-now clouds over, language calls attention to itself and no longer to the message. ${ }^{19}$

\section{Literally}

Now let ' $\mathrm{I}$ ' literize itSelf. Littering the marks of its/my presence in the pages of an already-past present, what here-and-now do(es) ' $I$ ' render? These literal transcriptions of a displaced presence plot themselves endlessly onto any time and space coordinate system. ' $L$ 'instance du discours' is multiple, infinitely repeatable; re-enacted, re-activated in the instance of reading, this instant transmutation (écriture to lecture) sunders the present from its original location. Uprooted, evicted from its temporary/temporal refuge, the literary ' ${ }^{\prime}$ ' takes on a migratory cast.

The implicitly present, seemingly inherent to unspoken language, is, thus, once spoken, once signified, immediately implicated in another time: the past of its own presence, marked in the trace of the signifier, and the future of its own re-enactment, given by the possibility of another reading. The literary ' $\mathrm{I}$ ' is a necessary explication of the migratory subject-in-process, forever en train de ..., straddling past, present and future, locating itSelf in the double instance of écriturelecture. ${ }^{20}$ 'In language and in the use of language, duplicity plays a cardinal role.'21

The written is doubly duplicitous: referring 'back' to a no-longer now and 'forward' to a possibly is, while re-enacting the here-andnow in a reader's present, the deliberately deceptivestatus of the literary text also confounds attempts to pin down the place of the person. ' $\mathrm{I}$ ' and 'you' no longer designate speaker and listener, but some kaleidoscopic hypostasis, an instantaneous stasis of a pyramidal positing between author, text, and reader.

'She,' then, is a fictitious fiction, a fiction within a fiction of an imaginary absent presence, realized solely within the confines of a literary 
possible world, and unlocatable except within that very imaginary universe of discourse.

\section{L'hommequi parle}

[Le discours est] la langue en tant qu'assumée parl'hommequi parle, et dans la condition d'intersubjectivité qui seule rend possible la communication linguistique. - Benveniste, PLG, 266.

'L'homme qui parle': two invisible appropriations combine to make imperceptible and inaccessible la femme qui écrit. Discourse, a running back and forth (dis-cursus) between fully constituted subjectivities, leaves undetected, unnoticeable, both women and writing, as if by rendering inconspicuous this subsumation - a taking up under of the hidden alterities - they will remain undetected, and more, incapable of being seen. This visionary lapsus is not just a metaphysical slippage, or an innocuous sliding of the signifier under the signified: when he speaks, man takes on language, assumes it as his own, enters the subjectivized area of linguistic communication through this very assumption.

When does language become discourse, and speech, writing? What is pernicious about this imperceptible lapse, and at what point precisely does it fall through? Language is converted into discourse, says Todorov ${ }^{22}$ through (not solely) the agency of the 'shifters' ${ }^{23}$ those empty deictic markers that stand outside denotative meaning, gesturing, pointing, showing, but remaining (like women) naturally, Naturely, mute and insignificant. ${ }^{24}$ It is by filling up the emptiness of deictic signals that man signifies his self in the present, takes on presence, and presents himSelf in the act of communication. Denoting, referring, appropriating proper names, marking his proper-ty through self-identification, man circumscribes the $O$, origo of the here-and-now. ${ }^{25}$ Through the agency of deictic anchoring in contextualized, concretized speech utterances, man traces out and fills in the O-mphal(l)us of his own subjectivity. Et la femme qui écrit? But what about (the) woman who writes?

\section{La femmequi écrit}

Aussitôt que produit, l'énoncé disparaît, si fond dans l'énonciation d'une nouvelle parole. Ephémère, sans laisser plus d'empreinte que le 
vol premier de l'oiseau ou que de fugaces étreintes. - Suzanne Lamy, D'elles (Montreal: Hexagone, 1979), p. 26.

[I]t is in the aspiration toward artistic and, in particular, literary creation that woman's desire for affirmation now manifests itself. Whyliterature? - Julia Kristeva, 'Women's Time,' trans. Alice Jardine, Signs 7, 1 (1981), p.31.

A woman is in the act of writing. Putting pen to paper, sheenters into a socio-symbolic contract, contractualizes herSelf into a signifying practice, and encodes the expression of herSelf into a series of signfunctions already negotiated by a community of language-users. The bargain has already been struck: the woman who writes is a woman being written.

Whether excluded from the dominant discourse or simply marginalized, the writing woman is also confronted by a sense of invisibility: her gender is subsumed under the imperialistic, supposedly ambisexual, appellation of man. Her writing is thus an act of affirmation, an attempt to make visible the fugacious flight of speech, to coalesce the ephemeral chatter of the second sex into a socially valued form.

But not all writing is Literature. The literary is a prescriptive principle, and canonization a process of power at work, inviting some texts into, and rejecting others from its hallowed hall of fame. The woman who writes maps out a strategy of acceptance or rejection according to the choices she makes: lexical, syntactical, narrative and discursive (genre) choices.

Her marks on the page graphically proclaim a graffiti-like affirmation of presence ('I was here,' scrawled on the back walls of the literary ante-chamber); but, at the same time, this very writing disassociates itself from its origin. It is bastardized speech, set loose to circulate unparented in a signifying economy. The graphic assertion of ' $\mathrm{I}$ ' is a locating function, an affirmation of here-and-now, but paradoxically, by not naming, by not assigning a proper name to this origo, the woman ${ }^{26}$ who chooses to use personal pronouns dis-locates herSelf, puts herSelf out of joint from the coordinating axes, displaces and shifts herSelf to an anonymous empty position, capable of being filled in and assumed by a multitude of readers. The ' $\mathrm{I}$ ' (and 'you'), assumed endlessly by the efforts of the reader, are thus more appropriable than 
the third person, which distances the reader by its meta-lingual and meta-fictional effect. She, at once, asserts, locates, dislocates, displaces, renders anonymous, and pluralizes herSelf by this act. A strategic move, then, in the literary game, to bring the reader 'closer' by allowing her / him to assume the origo of the already-past written present, but one which simultaneously proclaims its distance from the 'classic' novelistic genre, the murderous third-person narrative. The pronominal dislocation is duplex: shifting the space-time coordinates of the origo according to a reader's appropriation, it simultaneously displaces both writer and reader out of the literary confines of a fictional constraint.

This side-stepping gesture is also a nimble avoidance of the authoritarian function of the Author, a patriarchal posture assumed by the writer who 'fathers' the text, patents the literary product, propertizes his patrimony before putting it out to circulate as exchange-value in the economy of literary business. This public persona is nothing but another social construct, one that a woman skirts by continuing to write those traditionally 'female' forms such as the diary, the letter, and the first-person monologue addressed to a 'you'-listener.

A sense of alienation from the authoritarian/authorial function, then? An uncomfortable compromise in order to speak across the outer, marginalized frequencies of the patriarchal channels of Literature? More than likely, excluded from the anthologies of Great Books, and unwilling now to be recuperated into that tradition, the woman writing today finds in the first-person monologue an anonymous discourse, bordering on the confines between transcribed voice, autobiography (= herstory), and fiction, a fiction conceived outside the genres that have exluded her until now.

\section{Gender and Genre}

Emerged from the world of silence and whispering to the world of expression, from the time they first appear, women who write often are drawn to the margins of the literary scene. We find them in forms of literature, that, if not precarious or deprived of tradition, are certainly more fluid and easily realized. These are genres dominated, at least in appearance, by a logic of the fragment more than that of the completed project: collections of letters, epistolary novels, and diaries. Other female writers turn to autobiography, a genre that always leads to a 
difficult process of verification of her own identity (from the Greek graphía 'description,' autós 'one's own,' bíos 'life'). - Elisabetta Rasy, Le donne e la letteratura (Roma: Ed. Riuniti, 1978), p.93. My translation.

It seems to me that miming behaviour postulates from the beginning a refusal of the arbitrariness of the sign. In fact, such behaviour moves within the logic of the imaginary; the miming/mimetic illusion consists in the belief that the sign is a double of the thing, that there exists some relation of necessity between the two, that language adheres perfectly to reality in such a way as to mix up or blur the distinction between the two. It is this illusion that lies at the base both of epistolary writing as well as diary writing. - Laura Kreyder, 'Una donna banale,' Nuova Corrente 28, 86 (1981), p.504. My translation.

A clandestine denial of fictionality, a search for refuge in marginalized first-person forms, a development of "the logic of the fragment," a refusal of the arbitrariness of the sign ... thus I/woman write(s) my/ herSelf into the symbolic order while remaining, all the same, within the confines of the imaginary. Pursued ceaselessly around the borders of signification, barred from entry into the dominant male discourse, $\mathrm{V} / \mathrm{she}$ put(s) in stakes where language seems its most transparent, where fiction and reality superimpose: in the deployment of an Ivoice, telling the tale, describing my/her own life, as if the narration itself were nothing more than a description of an already-formed identity, rather than the very construction of that identity itself.

The illusion by which, between reality and the expression of reality that we give in confidences, in letters and in diaries, there exists only a link of naturalness, hides the fact that we order the data of the lived according to the laws of a story/history that has already been written. ${ }^{27}$

History/the story has already been written, but the passage from passive, spoken object to active, speaking subject can only take place in the act of narration. When I/woman tell(s) my/her story, appropriating a pronominal position, revealing the coordinates of here-andnow (but displacing and shifting that origo according to the unlocatable origin of lecture) while implicating the other in my/her enuncia- 
ation (donning and exchanging the mask of the persona), $\mathrm{I} /$ she also defy(ies) the fictionality of language, step(s) outside the generic constraints of Literature, refute(s) the power of Authorship, and enter(s) into the socio-symbolic order while at once remaining on its threshold. More precisely, I/she mark(s) the contours of my/her own identity, takes(s) on and trace(s) out the lineaments and substance of subjecthood.

\section{Notes}

1 'Contrairement à ce [qu'on croit], with-out n'enferme pas les expressions contradictoires "avec sans"; le sens propre de with est ici "contre" (cf. withstand) et marque pulsion ou effort dans une direction quelconque. De là with-in "vers l'intérieur" et with-out, "vers l'extérieur," d'ou "en dehors, sans."' Emile Benveniste, Problèmes de linguistique générale (Paris: Gallinard, 1966), p. 81.

2 See Catharine Belsey's Critical Practice (London: Methuen, 1980), pp. 64-7, for a succinct account of this Lacanian/Kristevan term. See also under 'process' in Leon S. Roudiez introductory glossary to Julia Kristeva, Desire in Language (Oxford: Basil Blackwell, 1980).

3 Benveniste, p. 262.

4 Benveniste, p. 262.

5 Karl Bühler, Speech, Place, and Action, R.J. Jarvella and W. Klein, eds. (Chichester: John Wiley and Sons, 1982), p. 12.

'Deictic' means simply 'pointing or showing directly.' John Lyons has defined deixis as '... the location and identification of persons, objects, events, processes and activities being talked about, or referred to, in relation to the spatio-temporal context created and sustained by the act of utterance.' (From Lyons, John. Introduction to Theoretical Linguistics. London: Cambridge Univ. Press, 1977; quoted by Mark Steedman in Speech, Place, and Action, p. 125.)

Lyons himself also notes (in Speech, Place, and Action, p. 106) that Peirce's term "index" is but one of a set of grammatical and philosophical terms, traditional and modern, all of which are based, in one way or another, upon the notion of pointing: "deixis," "demonstrative," "ostension," etc.' We could add 'shifters' to that list of terms.

See also Charles Fillmore, Santa Cruz Lectures on Deixis (Indiana Linguistic Club, 1975), p. 39: Deixis is the name given to those formal properties of utterances which are determined by, and which are interpreted by knowing, certain aspects of the communication act in which the utterances in question can play a role.'

Linguists identify three basic types of deixis: person (personal pronouns, 
proper names), place (eg. 'above,' 'there') and time (eg. 'yesterday,' 'next Tuesday').

6 Bühler, p. 12.

7 Cf. Bühler, 19: Briefly speaking, the words I and you refer to the role holders in the on-going speech drama, in the speech action. In prosopon, the Greeks had an excellent name for it, and the Romans meant nothing by persona but the role in the speech act. [...] The main and original function of personal pronouns like $I$ and you is not to denote sender and receiver, just as names denote, but only to refer to these role holders....'

8 Benveniste, p. 261.

9 Benveniste, p. 81.

10 Bühler, p. 19.

11 Roland Barthes, in The Structuralist Controversy, R. Macksey and E. Donato, eds. (Baltimore: Johns Hopkins, 1970), p. 144: Tnasmuch as person, tense and voice imply these remarkable linguistic beings - the "shifters" - they oblige us to conceive language and discourse no longer in terms of an instrumental and reified nomenclature, but in the very exercise of parole. The pronoun, for example, which is without doubt the most staggering of the "shifters," belongs structurally to [parole]. That is its scandal, if you like. ...'

12 Julia Kristeva, 'Tnstances du discours et altération du sujet,' Romanic Review 70,9 (1974), p. 77.

13 Benveniste, p. 260.

14 Kristeva, p. 86.

15 Note the double meaning of persona: in Latin it means 'mask.'

16 'Seule la "troisième personne," étant non-personne, admet un véritable pluriel.' Benveniste, p. 236.

17 "Je," extirpé de sa position, s'accroche donc à un "il" qui, pour être hors dialogue, ne désigne aucun énonciateur de l'act discursif en cours, mais marque simplement et objectivement la possibilité d'une instance de discours.' Kristeva, p. 82.

18 Kristeva, p. 90.

19 'IS]hifters are distinguished from all other constituents of the linguistic code solely by their compulsory reference to the given message.' Roman Jakobson, Selected Writings, Vol. 2 (The Hague: Mouton), p. 132.

Jakobson places shifters in the Peircean category of INDEXICAL SYMBOLS: signs that are associated with the represented object by a conventional rule, yet necessarily connected to that object by some existential relation. Certainly ' $I^{\prime}$ fits into this analysis, since the speaker is implicit to the act of utterance (i.e. is existentially related to the instance of discourse); but in what way is 's/he' existentially related to the object it represents? Rather the third person calls attention to the code itself by referring to the possibility of language to name the absent or fictional 
person. It is for this reason that I characterize the use of the third person as a metalingual function. (See Jakobson, Selected Writings, Vol. 7 (Berlin: Mouton, 1985), p. 116: 'A metalanguage is a language in which we speak about the verbal code itself.')

20 Cf. Jacques Derrida in The Structuralist Controversy, p. 155: When I look for the présent of discursive time, I don't find it. I find that this present is taken not from the time of the énonciation but from a movement of temporalization which poses the difference and consequently makes the present something complicated, the product of an original synthesis which also means that the present cannot be produced except in the movement which retains and effaces it.'

21 Jakobson, Vol. 2, p. 133. Jakobson's use here of the word 'duplicity' refers to the duplex functioning of message and code which '... may at once be utilized and referred to $\left(=\right.$ and pointed at) ${ }^{\prime}(\mathrm{p} .130)$.

22 Tzvetan Todorov, The Structuralist Controversy, p. 316.

23 Kristeva recalls Jakobson's definition of shifters: 'des pronoms dans la locution ... qui translatent le code dans le message, le procès de l'énoncé dans le procès de l'énonciation, les divers protagonistes de l'un dans l'autre et vice versa.' She adds: 'C'est donc dans la locution elle-même que les pronoms jouent le role d'échangeurs entre divers niveaux et aspects de l'acte et du système linguistique. La fiction ne ferait alors que mettre en évidence le caractère de charnière de ces instances, en faisant jouer les translations non seulement entre code et message, énoncé et énonciation, mais dans tous les sens et à l'intérior de chacune de ces divisions.' (pp. 78-79.)

24 Note the double meaning of this word: 1. unimportant, 2. non-signifying.

25 See Hélène Cixous, Le sexe ou la tête?,' in Les Cahiers du GRIF, 13 (1976), pp. 5-15, for a discussion of the Realm of the Proper, identified with the male; and Luce Irigaray, Ce sexe qui n'en est pas un (Paris: Editions de Minuit, 1977).

26 Or man, of course.

27 Laura Kreyder, Una donna banale,' Nuovo Corrente 28, 86 (1981), p. 511. My translation. 